\title{
Interleukin-1 $\beta$ Modulates the Growth and Phenotype of Neonatal Rat Cardiac Myocytes
}

Cynthia M. Thaik, Angelino Calderone, Nobuyuki Takahashi, and Wilson S. Colucci

Cardiomyopathy Center and Cardiovascular Division, Department of Medicine, Brigham and Women's Hospital and Harvard Medical

School, Boston, Massachusetts 02115

\begin{abstract}
Mononuclear cell infiltration and local cytokine elaboration are hallmarks of inflammatory and immunologic heart diseases. To test the hypothesis that cytokines can modulate cardiac myocyte growth and phenotype, myocytes cultured from neonatal rat hearts were exposed to $I L-1 \beta$, an inflammatory cytokine prevalent in myocardial inflammation. $\mathrm{IL}-1 \beta(2 \mathrm{ng} / \mathrm{ml}, 24 \mathrm{~h})$ increased $\left[{ }^{3} \mathrm{H}\right]$ leucine incorporation by $30 \pm 4 \%(P<0.001, n=29)$ and net cellular protein content by $20 \pm 4 \%(P<0.001, n=27)$, but had no effect on DNA synthesis. Northern hybridization showed that IL-1 $\beta$ increased prepro-atrial natriuretic factor (ANF) mRNA (5.8 \pm 1.5 -fold, $P<0.01, n=13)$ and $\beta$-myosin heavy chain ( $\beta$-MHC) mRNA ( $>10$-fold, $n=4)$, and decreased mRNA levels for sarcoplasmic reticulum $\mathrm{Ca}^{2+}$-ATPase (SERCA2) $(-46 \pm 7 \% ; P<0.001 ; n=11)$, calcium release channel (CRC) $(-65 \pm 11 \%, P<0.001, n=8)$ and voltagedependent calcium channel (VDCC) $(-53 \pm 7 \%, P<0.001$, $n=8)$. $N^{\mathrm{G}}$-monomethyl-L-arginine $(1 \mathrm{mM})$, an inhibitor of nitric oxide (NO) synthesis, did not inhibit the IL-1ß-induced protein synthesis or changes in mRNA levels. In ventricular myocardium obtained from adult rats treated with lipopolysaccharide ( $4 \mathrm{mg} / \mathrm{kg}$ intraperitoneally $18 \mathrm{~h}$ ) to stimulate systemic cytokine production, there were changes in the mRNA levels for $\beta$-MHC $(6 \pm 1$-fold, $P<0.01, n=4)$, SERCA2 $(-65 \pm 4 \%, P<0.0001, n=4)$, CRC $(-67 \pm 5 \%$, $P<0.001, n=4)$, and VDCC $(-58 \pm 5 \%, P<0.001 ; n=4)$ that were qualitatively similar to those observed in cultured myocytes. Thus, IL-1ß, acting via an NO-independent mechanism, caused myocyte hypertrophy associated with induction of fetal genes (ANF and $\beta$-MHC) and downregulation of three important calcium regulatory genes (SERCA2,

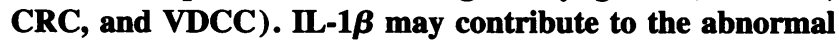
structural and functional alterations of cardiac myocytes in conditions marked by mononuclear cell infiltration. (J. Clin. Invest. 1995. 96:1093-1099.) Key words: cytokines • atrial natriuretic factor $\cdot \beta$-myosin heavy chain - sarcoplasmic reticulum calcium ${ }^{2+}$-ATPase - calcium release channel • voltage-dependent calcium channel
\end{abstract}

Address correspondence to Wilson S. Colucci, M.D., Cardiovascular Division, Brigham and Women's Hospital, 75 Francis St., Boston, MA 02115. Phone: 617-732-5894; FAX: 617-732-5132.

Received for publication 7 October 1994 and accepted in revised form 14 April 1995.

J. Clin. Invest.

(c) The American Society for Clinical Investigation, Inc.

0021-9738/95/08/1093/07 \$2.00

Volume 96, August 1995, 1093-1099

\section{Introduction}

There is mononuclear cell infiltration of the myocardium with local elaboration of inflammatory cytokines in a variety of cardiovascular conditions such as myocarditis and transplant rejection (1). The effects of inflammatory cytokines on cardiac myocyte growth and gene expression are not known. However, in hematopoietic, vascular smooth muscle and endothelial cells, inflammatory cytokines exert pleiotropic effects on cell growth, differentiation, and gene expression (2-4), and many of the signaling pathways activated by cytokines $(5,6)$ are known to be involved in regulating growth and gene expression in cardiac myocytes (7). In addition, cytokines induce nitric oxide (NO) ${ }^{1}$ production by upregulating expression of inducible nitric oxide synthase in cardiac myocytes $(8,9)$ and could therefore act via cGMP, which has been shown to modulate growth in vascular smooth muscle cells (10). Thus, it is possible that cytokines contribute to the structural and functional alterations of the myocardium observed in states associated with myocardial inflammation.

We hypothesized that exposure to inflammatory cytokines would cause myocyte hypertrophy associated with reexpression of fetal genes and downregulation of adult muscle-specific genes involved in maintaining calcium homeostasis. To test this hypothesis, cultured neonatal rat cardiac myocytes were exposed to $\mathrm{IL}-1 \beta$, an inflammatory cytokine prevalent in myocarditis $(11,12)$. We examined the effect of $I L-1 \beta$ on protein synthesis, DNA synthesis, the mRNA levels for three fetal genes (prepro-atrial natriuretic factor, ANF; $\beta$-myosin heavy chain, $\beta$-MHC; and skeletal $\alpha$-actin, $\alpha$-SkA), and the mRNA levels for three calcium regulatory genes (sarcoplasmic reticulum $\mathrm{Ca}^{2+}$-ATPase, SERCA2; calcium release channel, CRC; and voltage-dependent calcium channel, VDCC). The effect of $N^{\mathrm{G}}$ monomethyl-L-arginine (L-NMMA), an inhibitor of nitric oxide synthase (8), was determined to test the role of NO. To address the pathophysiologic relevance of the in vitro observations, we also examined the phenotypic changes induced in vivo in myocardium obtained from adult rats treated with LPS, a potent stimulus for elaborating several inflammatory cytokines (13).

\section{Methods}

Preparation of cultured neonatal rat ventricular myocytes. Neonatal cardiac myocytes were isolated by a modification of Kasten's technique (14), as previously described (15). Briefly, hearts were removed from

1. Abbreviations used in this paper: ANF, atrial natriuretic factor; $\alpha$ SkA, skeletal $\alpha$-actin; $\beta$-MHC, $\beta$-myosin heavy chain; CRC, calcium release channel; ITS, insulin/transferrin/selenium; NO, nitric oxide; PS, penicillin/streptomycin; RT, room temperature; SERCA2, sarcoplasmic reticulum $\mathrm{Ca}^{2+}$-ATPase; VDCC, voltage-dependent calcium channel. 
2-d-old Sprague-Dawley rats killed by decapitation. Ventricular tissues were incubated in $0.1 \%$ trypsin (Gibco Laboratories, Grand Island, NY) in HBSS (Gibco) overnight at $4^{\circ} \mathrm{C} .3-4$ digestions for $10 \mathrm{~min}$ each were performed with $10 \mathrm{ml}$ of $0.1 \%$ collagenase (Worthington Biochemical Corp., Freehold, NJ) in HBSS. The dissociated cells were collected by centrifugation at $1,000 \mathrm{rpm}$ for $4 \min \left(4^{\circ} \mathrm{C}\right)$, pooled, and resuspended in DME (Gibco) supplemented with 7\% FBS (Gibco) and $5 \mathrm{ml}$ penicillin/streptomycin (PS) (Gibco). To selectively enrich for myocytes, dissociated cells were preplated twice in T75 flasks (Corning Glass Works, Corning, NY) for $75 \mathrm{~min}$, during which period the nonmyocytes attached readily to the bottom of the cultured dish. The resultant cell suspension was cultured for $24 \mathrm{~h}$ in DME/FBS/PS with $0.1 \mathrm{mM}$ Bromodeoxyuridine (Sigma Chemical Co., St. Louis, MO) to prevent proliferation of nonmyocytes. The medium was changed to serum-free medium containing insulin ( $5 \mu \mathrm{g} / \mathrm{ml})$, transferrin $(5 \mu \mathrm{g} / \mathrm{ml})$, and sodium selenite $(5 \mathrm{ng} / \mathrm{ml}$ ) (ITS) (Sigma) for $24 \mathrm{~h}$ before treatment.

LPS treatment of adult rats. Male Sprague-Dawley rats weighing 200-250 grams were obtained from Charles River Laboratories (Kingston, NY). LPS from Salmonella typhimurium (Sigma) $(4 \mathrm{mg} / \mathrm{kg}$ ) was injected intraperitoneal $18 \mathrm{~h}$ before killing (16). The rats were anesthetized with ether, and the heart was rapidly excised and prepared for RNA isolation, as described later.

Incorporation of $\left[{ }^{3} \mathrm{H}\right]$ leucine. Cultured neonatal ventricular myocytes, plated at $200-400$ cells $/ \mathrm{mm}^{2}$ (low density) and at 1,000 cells/ $\mathrm{mm}^{2}$ (high density) in 24-well plates were treated with $0.02-4 \mathrm{ng} / \mathrm{ml}$ IL-1 $\beta$ (R \& D Systems, Inc., Minneapolis, MN) and coincubated with $2 \mu \mathrm{Ci} / \mathrm{ml}\left[{ }^{3} \mathrm{H}\right]$ leucine (Dupont-NEN, Boston, MA) for $24 \mathrm{~h}$, unless otherwise stated. Cells were washed twice with PBS and treated with $5 \% \mathrm{TCA}$ at $4^{\circ} \mathrm{C}$ for $30 \mathrm{~min}$ to precipitate protein. The precipitates were washed twice with ice-cold water and resuspended in $0.4 \mathrm{M} \mathrm{NaOH}$. Aliquots were counted by a scintillation counter. To examine the effect of IL- $1 \beta$ on protein degradation, cells were labeled to isotopic equilibrium by incubating for $48 \mathrm{~h}$ with $\left[{ }^{3} \mathrm{H}\right]$ leucine. Cells were then washed to remove extracellular $\left[{ }^{3} \mathrm{H}\right]$ leucine before treatment with $\mathrm{IL}-1 \beta$ for an additional $24 \mathrm{~h}$. The labeled cells were harvested as described earlier.

Incorporation of $\left[{ }^{3} \mathrm{H}\right]$ thymidine. After culturing for $24 \mathrm{~h}$ in serumfree medium, neonatal cells in 24-well plates $\left(200-400\right.$ cells $\left./ \mathrm{mm}^{2}\right)$ were treated with IL-1 $\beta$ for $24 \mathrm{~h}$. After $18 \mathrm{~h},\left[{ }^{3} \mathrm{H}\right]$ thymidine $(2 \mu \mathrm{Ci} /$ ml) (Dupont-NEN) was added for the last $6 \mathrm{~h}$ before harvest, as described earlier.

Protein content. Net protein synthesis was measured in neonatal myocytes plated at $200-400$ cells $/ \mathrm{mm}^{2}$ in 6-well plates (control cells

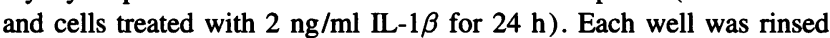
two times with PBS and scraped into immunoprecipitation buffer (1\% Triton X-100, $150 \mathrm{mM} \mathrm{NaCl}, 10 \mathrm{mM}$ Tris, pH 7.4, $1 \mathrm{mM}$ EDTA, 1 mM EGTA, $0.2 \mathrm{mM}$ sodium vanadate, $0.2 \mathrm{mM}$ PMSF, $0.5 \% \mathrm{NP}-40$ ). Protein content was measured by Bradford assay (17).

Beating rate. The spontaneous beating was examined in control cells and cells incubated with $2 \mathrm{ng} / \mathrm{ml} \mathrm{IL}-1 \beta$ for $24 \mathrm{~h}$. Cells plated at a density of 1,000 cells $/ \mathrm{mm}^{2}$ were maintained in serum-free DME/ITS/ PS for $24 \mathrm{~h}$ before addition of the IL-1 $\beta$. Beating rate (expressed as beats per min) was measured by counting the number of beats in $15 \mathrm{~s}$ using the $40 \times$ objective on a phase-contrast microscope (Nikon Inc., Instr. Group, Melville, NY).

Assessing the nitric oxide pathway. The role of nitric oxide in protein synthesis and gene regulation was assessed using L-NMMA ( $1 \mathrm{mM})$, an inhibitor of nitric oxide synthase. Neonatal cardiac myocytes were prepared as described earlier. After $1 \mathrm{~d}$ of culture in a serum-free media, cells were incubated for $4 \mathrm{~h}$ in L-arginine-depleted culture medium (MEM, Select Amine; GIBCO BRL, Gaithersburg, MD), containing either $1 \mathrm{mM}$ L-arginine (for control cells) or $1 \mathrm{mM} \mathrm{L}$-NMMA (Calbiochem Corp., La Jolla, CA), before IL-1 $\beta(2 \mathrm{ng} / \mathrm{ml}, 24 \mathrm{~h}$ ) exposure. Cells were used for $\left[{ }^{3} \mathrm{H}\right]$ leucine incorporation experiments and Northern hybridizations (described later).

To confirm that L-NMMA inhibited NO production, cGMP levels were used as markers of IL- $1 \beta$-induced NO synthesis. Myocyte cGMP content was measured using a standard radioimmunoassay kit (Biomedical Technologies, Inc., Stoughton, MA) (18). Cells were treated as described previously. 3-isobutyl-1-methylxanthine (1 mM) (Sigma) was added to cell culture $1 \mathrm{~h}$ before assay termination with $0.1 \mathrm{M}$ hydrochloric acid. cGMP was determined by RIA and expressed as picomoles per milligram of protein.

RNA preparation and Northern hybridization of neonatal myocytes. Neonatal ventricular myocytes, plated in 100 -mm cultured plates at high density $\left(1,000\right.$ cells $\left./ \mathrm{mm}^{2}\right)$ unless specified otherwise, were treated with IL-1 $\beta$ for $21-27 \mathrm{~h}$. Cells were resuspended in denaturing solution (4 $\mathrm{M}$ guanidium thiocyanate, $25 \mathrm{mM}$ Na citrate, $0.5 \% \mathrm{~N}$-laurylsarcosine, $0.1 \mathrm{M} \beta$-mercaptoethanol, $\mathrm{pH}$ 7.0). Total RNA was isolated by a modification of technique by Chomczynski and Sacchi (19) and quantitated by spectrophotometry. RNA was denatured with formaldehyde and formamide, and separated by size electrophoresis on a $1.3 \%$ agarose $/ 4 \%$ formaldehyde gel ( $15 \mu \mathrm{g}$ total RNA per lane). RNA was transferred to nylon membranes (Genescreen Plus; DuPont-NEN) by capillary transfer and crosslinked by UV Stratalinker 1800 (Stratagene, La Jolla, CA).

Rat cDNAs for prepro-ANF (courtesy of Dr. Christine Seidman, Harvard Medical School), a rabbit cDNA for SERCA2 (courtesy of Dr. Jonathan Lytton, Harvard Medical School), a rabbit cDNA for CRC (courtesy of Dr. Andrew R. Marks, Mount Sinai School of Medicine, New York), a rat cDNA for the $\alpha_{1}$ subunit of cardiac calcium channel dihydropyridine receptor (VDCC) (courtesy of Dr. James D. Marsh, Wayne State University, Detroit, MI), and a 136-bp EcoR1 fragment of the human $\alpha$-SkA $3^{\prime}$-untranslated region pHM $\alpha$ A-3'UT-Fnu (courtesy of Dr. James L. Lessard, Harvard Medical School) were labeled with $\left.{ }^{32} \mathrm{P}\right] \mathrm{dCTP}$ (Dupont) to a specific activity of $1-2 \times 10^{6} \mathrm{cpm} / \mathrm{ng}$ cDNA by the random hexamer priming method, and hybridized to nylon blots for $18-24 \mathrm{~h}$ at $42^{\circ} \mathrm{C}$, as previously described $(20)$. Blots hybridized with prepro-ANF and SERCA2 cDNA were washed twice (15 min, room temperature [RT] $)$ with $2 \times \mathrm{SSC}(1 \times \mathrm{SSC}, 150 \mathrm{mM} \mathrm{NaCl}, 15$ $\mathrm{mM}$ trisodium citrate, $\mathrm{pH} 7.0) / 0.1 \%$ SDS and twice $\left(15 \mathrm{~min}, 60^{\circ} \mathrm{C}\right)$ with $0.2 \times$ SSC $/ 0.1 \%$ SDS. Blots hybridized with $\alpha$-SkA cDNA were washed twice ( $15 \mathrm{~min}, \mathrm{RT})$ with $4 \times \mathrm{SSC} / 0.1 \%$ SDS and twice $(10$ $\min , 42^{\circ} \mathrm{C}$ ) with $4 \times \mathrm{SSC} / 0.1 \%$ SDS. Blots hybridized to CRC and VDCC were washed twice $(15 \mathrm{~min}, \mathrm{RT})$ with $2 \times \mathrm{SSC} / 0.1 \%$ SDS and once $\left(5-20 \mathrm{~min}, 45^{\circ} \mathrm{C}\right)$ with $0.5 \times \mathrm{SSC} / 0.1 \% \mathrm{SDS}$. A synthetic oligonucleotide probe 20 bases in length was constructed complementary to the $3^{\prime}$ untranslated region of the rat $\beta$-MHC mRNA (GGTCTCAGGGCTTCACAGGC) (21). The probe was labeled with [ ${ }^{32} \mathrm{P}$ ]ATP (Dupont-NEN) at the $5^{\prime}$ end using $\mathrm{T}_{4}$ polynucleotide kinase to a specific activity of $2 \times 10^{7} \mathrm{cpm} / \mu \mathrm{g}$. Blots hybridized with the $\beta$-MHC oligonucleotide probe were washed twice $(15 \mathrm{~min}, \mathrm{RT})$ with $4 \times \mathrm{SSC} /$ $0.1 \%$ SDS and twice $\left(10 \mathrm{~min}, 42^{\circ} \mathrm{C}\right)$ with $4 \times \mathrm{SSC} / 0.1 \%$ SDS. The relative amount of mRNA per lane was determined by exposing the washed blots to Kodak XAR film (Eastman Kodak Co., Rochester, NY) with an intensifying screen at $-70^{\circ} \mathrm{C}$, and measuring the density of the exposed band with a laser densitometer (Ultrascan 2202; LKB, Sweden). The sizes of the hybridized messages were estimated using the $18 \mathrm{~S}$ and $28 \mathrm{~S}$ ribosomal RNA bands as standards.

All blots were reprobed with a ${ }^{32} \mathrm{P}$-labeled oligonucleotide complementary to $18 \mathrm{~S}$ ribosomal RNA, washed, and autoradiographed as previously described (20). Levels of mRNA reported here are normalized to the level of $18 \mathrm{~S}$ rRNA to correct for potential differences in the amount of RNA loaded and transferred.

RNA preparation from LPS-treated animals. Left ventricular myocardium from LPS-treated animals was immersed in denaturing solution ( $4 \mathrm{M}$ guanidium thiocyanate, $25 \mathrm{mM} \mathrm{Na}$ citrate, $0.5 \% \mathrm{~N}$-laurylsarcosine, $0.1 \mathrm{M} \beta$-mercaptoethanol, $\mathrm{pH} 7.0$ ) and immediately homogenized at maximum speed $(10 \mathrm{~s}, \times 2)$ with a polytron (Tekmar, Cincinnati, $\mathrm{OH})$. Total RNA was isolated by a modification of Chomczynski and Sacchi's technique (19). RNA was denatured with formaldehyde and formamide and separated by size electrophoresis on $1.3 \%$ agarose $/ 4 \%$ formaldehyde gel ( $30 \mu \mathrm{g}$ total RNA/lane). Filters were hybridized to the various probes and washed as described previously.

Statistical analysis. All data are presented as the mean \pm SEM. Statistical analysis was performed using the Student's $t$ test or StudentNewman Keuls's test with one-way analysis of variance, as appropriate. A $P$ value $<0.05$ was considered significant. 

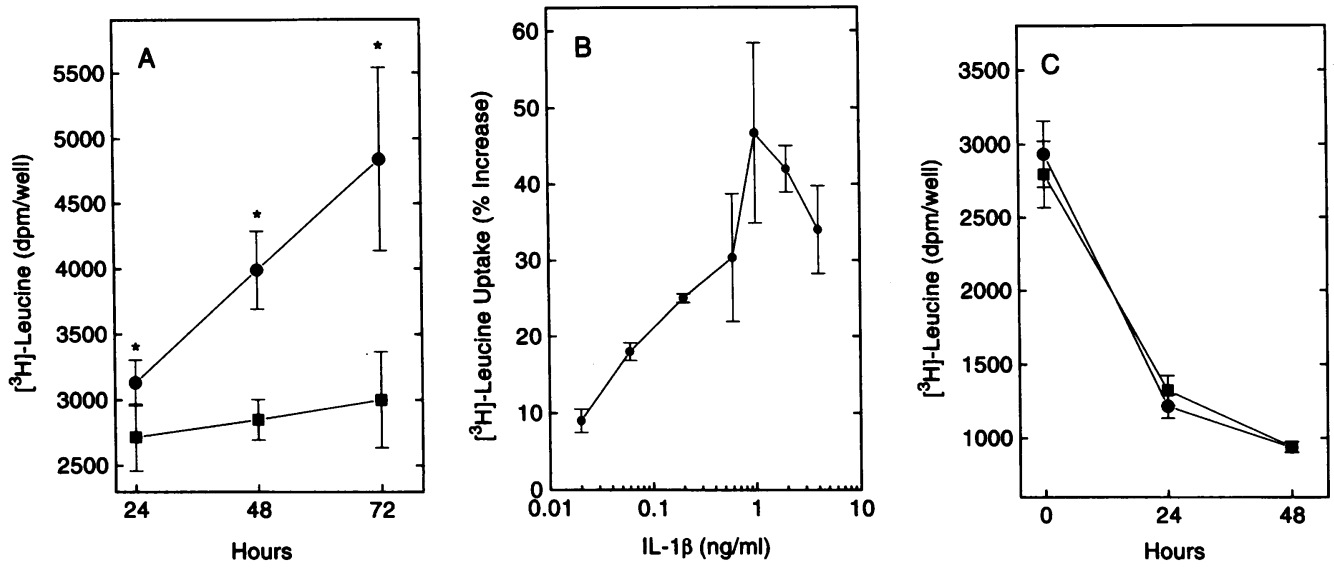

Figure 1. (A) Time course of $\left[{ }^{3} \mathrm{H}\right]$ leucine incorporation in control myocytes (squares) versus myocytes exposed to IL-1 $\beta(2 \mathrm{ng} / \mathrm{ml})($ circles). IL$1 \beta$ induced a $17 \pm 6 \%$ increase in $\left[{ }^{3} \mathrm{H}\right]$ leucine incorporation (versus control) at $24 \mathrm{~h} ;$ a $40 \pm 6 \%$ increase at $48 \mathrm{~h}$; and a $59 \pm 12 \%$ increase at $72 \mathrm{~h}$. Data represent means of five experiments, each performed in triplicate. ${ }^{*} P<0.01$ vs. control. $(B)$ Concentration dependence of the effect of IL$1 \beta$ exposure $(48 \mathrm{~h})$ on $\left[{ }^{3} \mathrm{H}\right]$ leucine incorporation in neonatal rat cardiac myocytes. The data are the means of three experiments, each performed in triplicate. $(C)$ Time course of $\left[{ }^{3} \mathrm{H}\right]$ leucine $(2 \mu \mathrm{Ci} / \mathrm{ml})$ release from control myocytes (squares) versus $\mathrm{IL}-1 \beta(2 \mathrm{ng} / \mathrm{ml})$-treated myocytes (circles) labeled to isotopic equilibrium. Data represent means of four experiments, each performed in triplicate.

\section{Results}

Effect of IL-1 $\beta$ on $\left[{ }^{3} \mathrm{H}\right]$ leucine uptake and protein content. In neonatal cardiac myocytes cultured at low density, exposure to IL-1 $\beta(2 \mathrm{ng} / \mathrm{ml})$ caused a time-dependent increase in $\left[{ }^{3} \mathrm{H}\right]-$ leucine incorporation $(17 \pm 6,40 \pm 6$, and $59 \pm 12 \%$ at 24,48 , and $72 \mathrm{~h}$, respectively; $P<0.01$ at each time point, $n=5$; Fig. $1 A$ ), indicating that $\mathrm{IL}-1 \beta$ increases $\left[{ }^{3} \mathrm{H}\right]$ leucine incorporation into protein. In 29 experiments, the mean increase in $\left[{ }^{3} \mathrm{H}\right]-$ leucine uptake over control at $24 \mathrm{~h}$ was $30 \pm 4 \%(P<0.001)$. In myocytes plated at high density, IL- $1 \beta$ exposure for $24 \mathrm{~h}$ caused a similar $30 \pm 10 \%$ increase in $\left[{ }^{3} \mathrm{H}\right]$ leucine uptake $(P$ $<0.02, n=8$ ). This effect of $\mathrm{IL}-1 \beta$ was concentration dependent, with a threshold of $\sim 0.02 \mathrm{ng} / \mathrm{ml}$, and a plateau between 1 and $4 \mathrm{ng} / \mathrm{ml}$ (Fig. $1 B$ ).

Compared with control, $\mathrm{IL}-1 \beta(2 \mathrm{ng} / \mathrm{ml}, 24 \mathrm{~h})$ caused a $20 \pm 4 \%$ increase in net protein content $(P<0.001, n=27$; Fig. $2 A)$ and a $22 \pm 8 \%$ increase in total RNA content $(P$
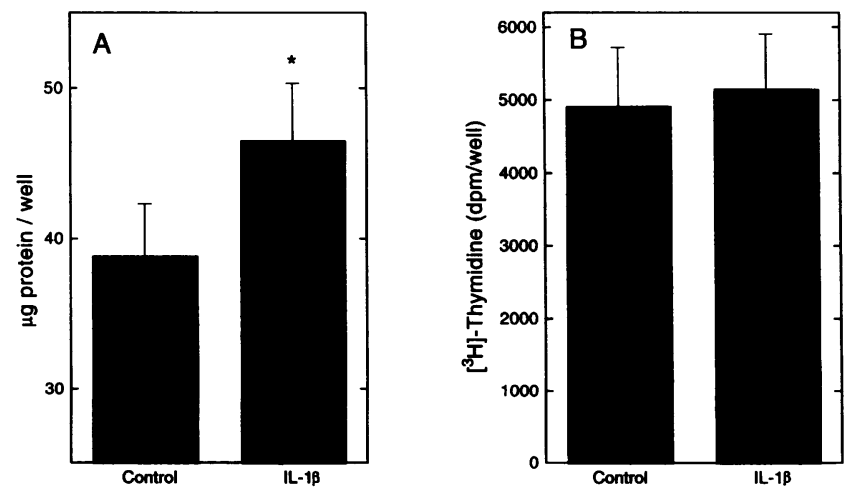

Figure 2. (A) Effect of interleukin-1 $\beta(2 \mathrm{ng} / \mathrm{ml}, 24 \mathrm{~h})$ on net cellular protein content. The data are means of 27 individual wells from eight experiments. * $P<0.001$ vs. control. $(B)$ Effect of $\mathrm{IL}-1 \beta(2 \mathrm{ng} / \mathrm{ml}$, $24 \mathrm{~h}$ ) on DNA synthesis as assessed by $\left[{ }^{3} \mathrm{H}\right]$ thymidine incorporation into control and IL-1 $\beta(2 \mathrm{ng} / \mathrm{ml})$-treated myocytes. The data represent means of 10 experiments, each performed in triplicate.
$<0.02, n=16$ ), indicating that the increased $\left[{ }^{3} \mathrm{H}\right]$ leucine incorporation is associated with an increase in net protein and RNA synthesis.

Effect of $I L-1 \beta$ on $\left[{ }^{3} \mathrm{H}\right]$ thymidine uptake. $\mathrm{IL}-1 \beta$ had no effect on $\left[{ }^{3} \mathrm{H}\right]$ thymidine uptake over $24 \mathrm{~h}(4,910 \pm 812$ vs. $5,146 \pm 760 \mathrm{dpm} ; P=\mathrm{NS}, n=10$; Fig. $2 B$ ). These findings indicate that IL- $1 \beta$ causes myocyte hypertrophy in the absence of hyperplasia, an effect similar to that caused by several hypertrophic stimuli, including norepinephrine, angiotensin, endothelin, some peptide growth factors (e.g., basic fibroblast growth factor), and stretch (22-26).

Effect of IL-1 $\beta$ on release of $\left[{ }^{3} H\right]$ leucine. $\mathrm{IL}-1 \beta$ had no effect on the rate of $\left[{ }^{3} \mathrm{H}\right]$ leucine release from cells labeled to isotopic equilibrium, suggesting that protein degradation is not accelerated by $\mathrm{IL}-1 \beta$ exposure (Fig. $1 C$ ). Thus, $\mathrm{IL}-1 \beta$ does not affect the rate of protein catabolism.

Effect of $I L-1 \beta$ on beating rate. In high density cultures, control myocytes formed a syncytium with a beating rate of $138 \pm 7 \mathrm{bpm}$. In cells treated with IL-1 $\beta(2 \mathrm{ng} / \mathrm{ml})$ for $24 \mathrm{~h}$, the beating rate was unchanged at $145 \pm 5 \mathrm{bpm}(P=\mathrm{NS}, n$ $=15$ ).

Effect of nitric oxide on $I L-1 \beta$-induced myocyte hypertrophy. Inflammatory cytokines may attenuate the biochemical and physiologic responses of the myocyte to $\beta$-adrenergic stimulation via an NO-mediated mechanism (8). We therefore examined the role of NO in mediating IL- $1 \beta$-induced myocyte hypertrophy. L-NMMA, an inhibitor of nitric oxide synthase, did not inhibit IL- $1 \beta$-induced $\left[{ }^{3} \mathrm{H}\right]$ leucine incorporation. In these experiments, IL- $1 \beta$ caused a $25 \pm 9 \%$ increase in $\left[{ }^{3} \mathrm{H}\right]$ leucine uptake at $24 \mathrm{~h}(P=0.02, n=8$; Fig. $3 A)$, and L-NMMA alone had no effect on $\left[{ }^{3} \mathrm{H}\right]$ leucine incorporation. The magnitude of IL- $\beta$-induced $\left[{ }^{3} \mathrm{H}\right]$ leucine incorporation in the presence of $\mathrm{L}$ NMMA $(24 \pm 7 \%)$ was no different from that caused by IL-1 $\beta$ alone ( $P=$ NS vs. IL- $1 \beta, n=8$; Fig. $3 A$ ), suggesting that the hypertrophic effect of IL-1 $\beta$ does not depend on NO synthesis.

To confirm that L-NMMA inhibited NO production in these experiments, cGMP levels were measured as a marker of IL$1 \beta$-induced NO synthesis. IL- $1 \beta$ increased cGMP levels ap- 

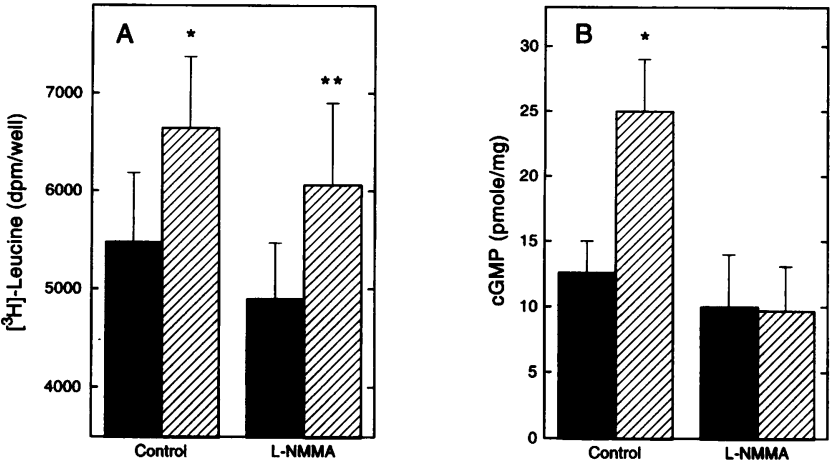

Figure 3. (A) Effect of L-NMMA, an inhibitor of nitric oxide synthase, on IL- $1 \beta$-induced myocyte growth as assessed by $\left[{ }^{3} \mathrm{H}\right]$ leucine incorporation in control myocytes (solid bars) and IL-1 $\beta(2 \mathrm{ng} / \mathrm{ml})$-treated myocytes (hatched bars). L-NMMA ( $1 \mathrm{mM}$ ) had no effect on IL-1 $\beta$ induced $\left[{ }^{3} \mathrm{H}\right]$ leucine incorporation. Data represent means of eight experiments, each performed in triplicate. ${ }^{*} P<0.02$ vs. control; ${ }^{* *} P$ $<0.01$ vs. control. $(B)$ Effect of L-NMMA on IL-1 $\beta$-induced cGMP production, which was used as a marker of NO synthesis, in control (solid bars) and IL-1 $\beta$-treated (hatched bars) myocytes. L-NMMA ( $1 \mathrm{mM}$ ) abolished IL-1 $\beta$-induced cGMP production. Data represent means of 11 control and 3 L-NMMA experiments, each performed in duplicate. ${ }^{*} P<0.001$ vs. control.

proximately twofold, from $12.6 \pm 2.4$ to $25 \pm 4 \mathrm{pmol} / \mathrm{mg}$ protein $(P<0.001, n=11 ;$ Fig. $3 B)$. L-NMMA had no effect on the basal cGMP level $(9.7 \pm 3.4 \mathrm{pmol} / \mathrm{mg}$ protein $)$ but abolished the IL- $1 \beta$-induced increase in cGMP $(10 \pm 4 \mathrm{pmol} / \mathrm{mg}$ protein; $P$ $=$ NS vs. L-NMMA alone, $n=3$; Fig. $3 B$ ), confirming that NO synthesis was inhibited by our protocol.

Induction of a fetal gene program in association with hypertrophy. Several hypertrophic stimuli have been shown to induce a fetal gene program associated with the repression of adult muscle-specific gene expression $(7,25,26)$. In high density cultures of neonatal rat myocytes exposed to $\mathrm{IL}-1 \beta(2 \mathrm{ng} / \mathrm{ml}$, $24 \mathrm{~h}$ ), the level of ANF mRNA was increased by $5.8 \pm 1.5$-fold $(P<0.01, n=13$; Figs. $4 A$ and $5 A)$. $\beta$-MHC mRNA was not detectable or only faintly visible in control myocytes, but was expressed at high levels in IL- $1 \beta$-treated myocytes (estimated; $>10$-fold induction; $n=4$; Figs. $4 A$ and $5 A$ ). Exposure to IL- $1 \beta$ for $24 \mathrm{~h}$ had no effect on the level of $\alpha$-SkA mRNA (1.1 \pm 0.1 -fold; $P=$ NS, $n=11$; Figs. $4 A$ and $5 A$ ). In the presence of L-NMMA, the induction of ANF mRNA (9.4 $\pm 6-$ fold; $P \cdot 0.01, n=4$; Fig. 6 ) and $\beta$-MHC mRNA (estimated; $>10$-fold induction; $n=2$ ) was not attenuated compared with the effect of IL- $1 \beta$ alone, suggesting that NO does not mediate the induction of the fetal gene program by IL- $1 \beta$. In low density $\left(200-400\right.$ cells $/ \mathrm{mm}^{2}$ ) cultures of neonatal rat myocytes, IL-1 $\beta$ for $24 \mathrm{~h}$ had an effect on ANF mRNA levels (7.1 \pm 1.7 -fold induction; $P<0.01, n=6$ ) that was qualitatively similar to that seen in high density cultures.

Regulation of major calcium regulatory genes. In parallel studies, we examined the regulation of mRNA levels for three proteins involved in maintaining calcium homeostasis in cardiac myocytes. In high density cultures of neonatal rat myocytes exposed to IL- $1 \beta$ for $24 \mathrm{~h}$, there were decreases in the mRNA levels for SERCA2 $(-46 \pm 7 \% ; P<0.001, n=11)$, CRC $(-65 \pm 11 \% ; P<0.001, n=8)$, and VDCC $(-53 \pm 7 \% ; P$ $<0.001, n=8$ ) (Figs. $4 B$ and $5 B$ ). In the presence of LNMMA, the magnitude of the IL- $\beta$-induced decreases in
A
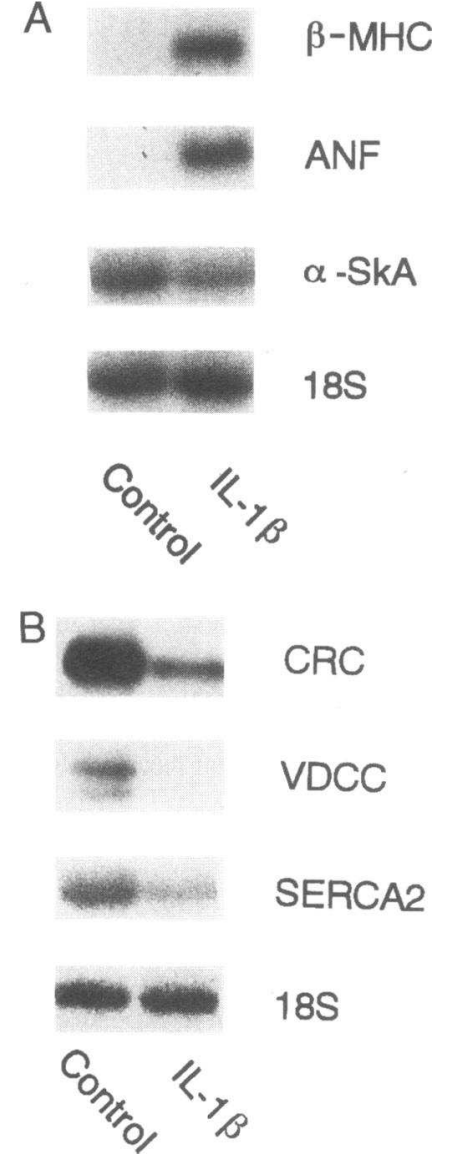

Figure 4. (A) A representative Northern hybridization depicting the effect of IL-1 $\beta$ ( 2 $\mathrm{ng} / \mathrm{ml}, 24 \mathrm{~h}$ ) on the levels of mRNA for $\beta$-MHC, ANF, and $\alpha$-SkA. Probes for $\beta$-MHC, ANF, and $\alpha$-SkA hybridized to bands at $7.2,0.9$, and $1.8 \mathrm{~kb}$, respectively. The level of $18 \mathrm{~S}$ rRNA, determined by hybridizing to an oligonucleotide complimentary to $18 \mathrm{~S}$ rRNA, was used to control for differences in mRNA loading and transfer. $(B)$ A representative Northern hybridization depicting the effect of IL- $1 \beta(2 \mathrm{ng} / \mathrm{ml}, 24 \mathrm{~h})$ on the mRNA levels for the CRC, the VDCC, and the SERCA2. CDNA for CRC, VDCC, and SERCA2 hybridized to bands at 16,8 , and $4 \mathrm{~kb}$, respectively. $18 \mathrm{~S}, 18 \mathrm{~S}$ rRNA.

mRNA levels for SERCA2 $(-68 \pm 8 \% ; P<0.01, n=4$; Fig. $6)$, CRC ( $-79 \pm 6 \% ; P<0.01, n=4)$, and VDCC $(-79 \pm 18 \%$; $P<0.01, n=3$ ) were not reduced, suggesting that NO synthesis is not involved in this action of IL-1 $\beta$.

Effect of LPS on myocardial gene expression in vivo. The intraperitoneal administration of LPS has been shown to induce expression of inflammatory cytokines, including IL-1 $\beta$ (27). In left ventricular myocardium obtained from rats treated with intraperitoneal LPS ( $4 \mathrm{mg} / \mathrm{kg}$ intraperitoneally, $18 \mathrm{~h}$ ), there was a $2.0 \pm 0.7$-fold ( $P=\mathrm{NS}, n=4$; data not shown $)$ induction of prepro-ANF mRNA and a $6.4 \pm 0.8$-fold $(P<0.01, n=4$; Fig. 7) induction of $\beta$-MHC mRNA. These changes in fetal gene expression were associated with a $65 \pm 4 \%$ decrease in SERCA2 mRNA, a $67 \pm 5 \%$ decrease in CRC mRNA, and a $58 \pm 5 \%$ decrease in VDCC mRNA $(P<0.001, n=4$; Fig. 7). These effects are qualitatively and quantitatively similar to the observations in cultured myocytes.

\section{Discussion}

The major new finding of this study is that $\mathrm{IL}-1 \beta$, a cytokine prominent in inflammatory conditions of the heart, causes hypertrophy of neonatal rat cardiac myocytes in vitro. This growth effect is associated with reexpression of fetal genes characteristic of hypertrophy (prepro-ANF and $\beta$-MHC) and downregulation of mRNA for three genes central to calcium homeostasis in cardiac myocytes (SERCA2, CRC, and VDCC). Cultured neonatal cardiac myocytes have been used extensively as a model system to study the mechanism of myocyte hypertrophy. 


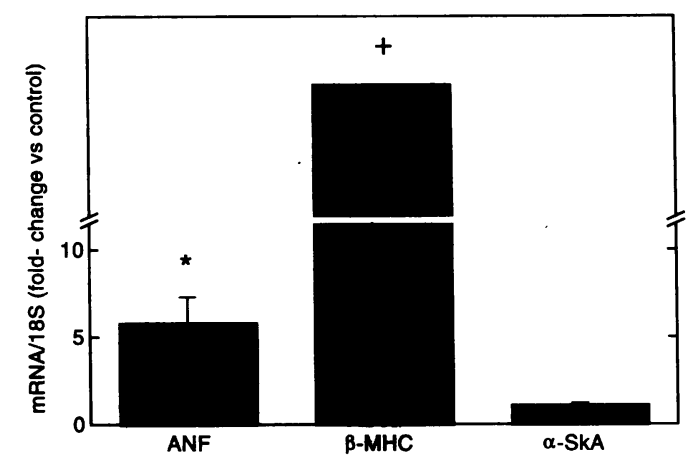

B

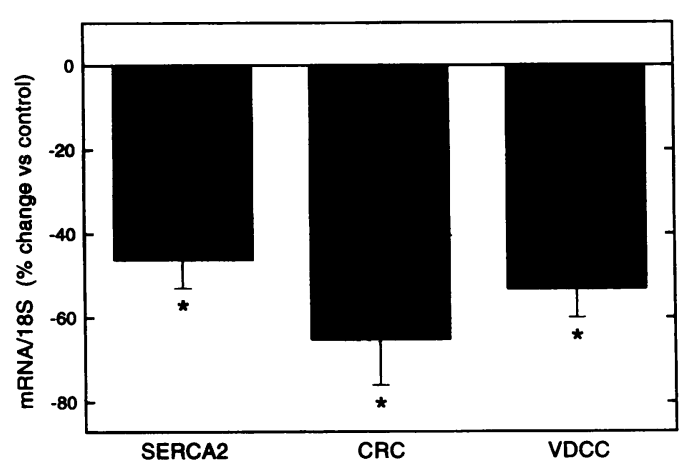

Figure 5. (A) Average changes in mRNA levels for ANF, $\beta$-MHC, and $\alpha$-SkA in cultured myocytes exposed to IL- $\beta(2 \mathrm{ng} / \mathrm{ml}, 24 \mathrm{~h})$. All mRNA levels are normalized to the level of $18 \mathrm{~S}$ rRNA as determined by Northern hybridization with an oligonucleotide probe. Data represent means of 4-13 experiments. ${ }^{*} P<0.01$ vs. control mRNA levels. $(+)$, nondetectable expression in control. Estimated induction is $>10$-fold in all filters examined. $(B)$ Average changes in the mRNA levels for SERCA2, CRC, and VDCC in myocytes exposed to IL-1 $\beta(2 \mathrm{ng} / \mathrm{ml}$, $24 \mathrm{~h}$ ). mRNA levels are normalized to levels of 18S rRNA. Data represent means of $8-11$ experiments. ${ }^{*} P<0.001$ vs. control mRNA levels.

In this system, adrenergic stimulation, angiotensin, endothelin, and peptide growth factors cause myocyte hypertrophy without hyperplasia $(22-26)$. We found that IL-1 $\beta$ likewise increased net protein and RNA content in the absence of DNA synthesis. $\left[{ }^{3} \mathrm{H}\right]$ Leucine release studies also showed that $\mathrm{IL}-1 \beta$-induced hypertrophy was not associated with increased protein breakdown.

Several observations suggest that cardiac hypertrophy is associated with a characteristic pattern of gene expression (7,

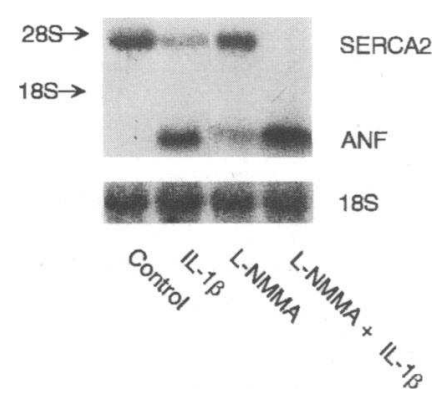

Figure 6. Representative Northern hybridization depicting the effect of L-NMMA ( $1 \mathrm{mM})$ on ANF and SERCA2 mRNA levels in control and IL-1 $\beta(2 \mathrm{ng} /$ $\mathrm{ml}, 24 \mathrm{~h}$ )-treated myocytes. $18 \mathrm{~S}, 18 \mathrm{~S}$ rRNA.

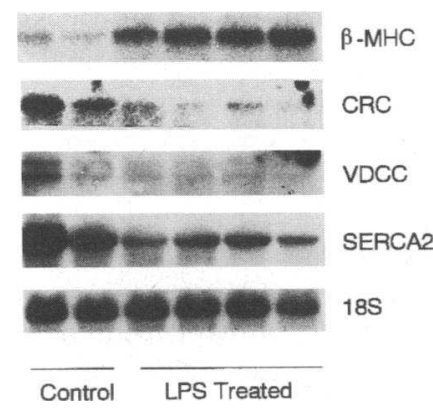

Figure 7. Effect of LPS on mRNA levels in adult rat left ventricular myocardium. Northern hybridization shows mRNA isolated from two control and four LPS ( $4 \mathrm{mg} / \mathrm{kg}$ intraperitoneally, $18 \mathrm{~h}$ ) treated rats. $18 \mathrm{~S}$, 18 rRNA

26). During hypertrophy, ventricular myocytes reexpress ANF, a feature lost in the normal postnatal ventricle. In addition, there is a switch at the mRNA level in the contractile protein isoforms from $\alpha$-MHC to $\beta$-MHC (7). In cultured neonatal cells exposed to $\mathrm{IL}-1 \beta$ for $24 \mathrm{~h}$, we found induction of prepro-ANF and $\beta$ MHC, but not $\alpha$-SkA. Although the failure of IL-1 $\beta$ to induce $\alpha$-SkA mRNA appears to distinguish it from several other agonists that induce myocyte hypertrophy, at least one other factor (acidic fibroblast growth factor) causes reciprocal changes in the levels of $\beta$-MHC (increased) and $\alpha$-SkA (decreased) mRNA $(25,28)$.

Several proteins, including SERCA2, CRC, and VDCC, play a central role in regulating systolic and diastolic calcium levels in myocytes (29). We found a downregulation of mRNA expression for all three calcium regulatory genes in response to $\mathrm{IL}-1 \beta$ in vitro and to LPS in vivo. Although it is reasonable to assume that decreased mRNA expression will ultimately result in decreased levels of these proteins, this remains to be determined. Likewise, further work is required to determine whether the observed changes in steady state mRNA levels are due to transcriptional versus posttranscriptional mechanisms.

SERCA2 mRNA has reportedly been reduced in pressure overload hypertrophy (30) and end-stage heart failure $(31,32)$. However, other studies have not found a decrease in SERCA2 mRNA in hypertrophy (33) or a decrease in the SERCA2 protein level in failing human myocardium (34). Relatively less is known about the expression of CRC and VDCC in hypertrophied or failing myocardium. CRC mRNA levels have been found to be decreased in myocardium obtained from patients with ischemic, but not idiopathic, dilated cardiomyopathy (35). VDCC mRNA and protein levels have been reported to be decreased in myocardium from patients with both ischemic and idiopathic dilated cardiomyopathy (36). Other investigators have shown that acute exposure of myocytes to cytokines attenuates intracellular calcium transients via an NO-independent mechanism (37). Our data suggest that tonic exposure to inflammatory cytokines could also affect calcium homeostasis and excitation-contraction coupling by downregulating the expression of calcium regulatory genes.

Roberts et al. $(9,38)$ have shown in neonatal rat cardiac myocytes that a 24 -h exposure to $\mathrm{IL}-1 \beta$ decreases the spontaneous beating rate. This effect is mediated by nitric oxide and requires the presence of either a fibroblast matrix or fibroblasts. Balligand et al. (8) have also implicated nitric oxide in mediating the negative inotropic effect of inflammatory cytokines on the cultured cardiac myocytes. In our studies, L-NMMA did not inhibit the hypertrophic response or the changes in gene expression, suggesting that in contrast to the effects of $\mathrm{IL}-1 \beta$ on beating rate and contractility, these effects of $\mathrm{IL}-1 \beta$ are not 
dependent on nitric oxide synthesis. We cannot exclude the possibility that NO is involved in regulating other genes by IL$1 \beta$. IL- $1 \beta$ treatment for $24 \mathrm{~h}$ did not affect the spontaneous beating rate, presumably because our cells were grown on plastic rather than a fibroblast matrix, which appears to be necessary for this effect to occur $(9,38)$.

Roberts et al. $(9,38)$ have further shown that TGF- $\beta_{1}$ can antagonize the ability of IL- $1 \beta$ to reduce beating rate in neonatal rat cardiac myocytes. We have reported that two hypertrophic stimuli, norepinephrine and pressure overload, induce the expression of TGF- $\beta_{1}$ in cardiac myocytes (15), and we have observed that IL- $1 \beta$, likewise, induces TGF- $\beta_{1}$ mRNA expression in cultured neonatal myocytes (our unpublished observations). The role of TGF- $\beta_{1}$ in modulating the effects of IL- $1 \beta$ on myocyte growth and phenotype is unclear. However, we have found that under the conditions of these experiments, the TGF- $\beta_{1}$ secreted by cultured neonatal cardiac myocytes in response to norepinephrine is inactive (15).

The mechanism by which IL- $1 \beta$ modulates growth and phenotype remains to be elucidated. Preliminary evidence suggests that protein kinase $\mathrm{C}$, tyrosine kinase, and mitogen-activated protein kinase may be involved (39). An IL- $\beta$-mediated change in beating rate does not appear to contribute, because under the conditions of these experiments (i.e., in the absence of a fibroblast matrix), this effect would not be expected (38) and was not observed. The observation that TGF- $\beta_{1}$ is induced by IL-1 $\beta$ further raises the possibility of an autocrine and/ or paracrine mechanism. It is noteworthy that in a myocytenonmyocyte coculture system, IL- $1 \alpha$ inhibited protein and mRNA synthesis, and this effect was due to the paracrine action of a soluble factor made by the nonmyocytes (40).

Because the myocyte cultures used in this study contain a small percentage of nonmyocytes (primarily fibroblasts), we cannot exclude the possibility that such cells are involved in mediating the observed effects of IL-1 $\beta$ (41). However, two observations argue against this possibility. First, in our cultures, IL- $1 \beta$ did not decrease beating rate, an effect Roberts et al. (38) have shown requires the presence of fibroblasts. Second, we found that IL- $1 \beta$ caused similar increases in $\left[{ }^{3} \mathrm{H}\right]$ leucine uptake and ANF mRNA induction in myocytes cultured at high and low densities, suggesting that cell density is not a critical determinant of these aspects of the growth response to IL- $1 \beta$. We cannot exclude an effect of cell density on the expression of other genes that were not examined in this study.

Since these experiments were performed in neonatal cells, it cannot be assumed that the observed effects of IL- $1 \beta$ are relevant to adult myocytes. However, a pattern of gene expression similar to that observed in cultured myocytes was induced in the ventricular myocardium of adult rats treated with LPS. LPS is a known potent stimulus for a variety of inflammatory cytokines (13). Several cytokines may be induced by LPS; therefore, we cannot implicate IL-1 $\beta$ as the major or sole effector in this model, nor can we exclude the role of hormonal factors (e.g., systemic catecholamines) that might be stimulated. Nevertheless, these in vivo observations are consistent with the in vitro data and support the general thesis that cytokines can modulate myocardial phenotype.

These findings provide a mechanism by which inflammatory cytokines could affect the structure and function of the myocardium. Inflammatory cytokines may be present in the myocardium during inflammatory states (e.g., acute myocarditis) and chronic immunologic stimulation (e.g., subacute myocarditis, transplant rejection, and idiopathic dilated cardiomyopathy). Recently, it has been proposed that inflammatory cytokines might be present in failing myocardium in the absence of a primary inflammatory process (42). In human myocarditis and transplant rejection, the extent of myocyte necrosis often correlates poorly with the extent of myocardial dysfunction $(43,44)$, consistent with the thesis that soluble inflammatory mediators released during the inflammatory process (e.g., IL-1 $\beta$ ) might mediate effects on myocardial structure and function. A clinical implication of our findings is that inhibitors of inflammatory cytokines, such as IL- $1 \beta$ receptor antagonists, might prove useful in ameliorating the structural and functional consequences of inflammatory and/or immunologically mediated myocardial processes.

\section{Acknowledgments}

We thank Drs. Nicholas J. Izzo, Jr., Jean-Luc Balligand, Krishna Singh, Ralph A. Kelly, and Thomas W. Smith for their generous scientific input. We appreciate the outstanding technical assistance of Olga Smirnova and are grateful to Paula McColgan for expert typing.

This work is supported in part by National Institutes of Health grant HL42539 to W. S. Colucci. C. M. Thaik is the recipient of a NIH National Research Service Award (HL08890-02). A. Calderone is a postdoctoral fellow of the Medical Research Council of Canada. W. S. Colucci was a Sandoz Established Investigator of the American Heart Association.

\section{References}

1. Zerbe, T. R. 1989. Contrast of mediators: identification of cells and cytokines in human heart tissue with acute rejection and myocarditis. Transplant. Proc. 21:443-444.

2. Mayani, H., W. Dragowska, and P. M. Lansdorp. 1993. Cytokine-induced selective expansion and maturation of erythroid versus myeloid progenitors from purified cord blood precursor cells. Blood. 81:3252-3258.

3. Libby, P., S. J. C. Warner, and G. B. Friedman. 1988. Interleukin-1: a mitogen for human vascular smooth muscle cells that induces the release of growth-inhibitory prostanoids. J. Clin. Invest. 81:487-498.

4. Cozzolino, F., M. Torcia, D. Aldinucci, M. Ziche, F. Almerigogna, D. Bani, and D. M. Stern. 1990. Interleukin 1 is an autocrine regulator of human endothelial cell growth. Proc. Natl. Acad. Sci. USA. 87:6487-6491.

5. Macchia, G., C. T. Baldari, A. Massone, and J. L. Telford. 1990. A role for protein kinase $\mathrm{C}$ activity in interleukin-1 (IL-1) induction of IL-2 gene expression but not in IL-1 signal transduction. Mol. Cell. Biol. 10:2713-2717.

6. Marczin, N., A. Papapetropoulos, and J. D. Catravas. 1993. Tyrosine kinase inhibitors suppress endotoxin- and IL-1 $\beta$-induced NO synthesis in aortic smooth muscle cells. Am. J. Physiol. 265:H1014-H1018.

7. Bilsen, M. V., and K. R. Chien. 1993. Growth and hypertrophy of the heart: towards an understanding of cardiac specific and inducible gene expression. Cardiovasc. Res. 27:1140-1149.

8. Balligand, J.-L., D. Ungureanu, R. A. Kelly, L. Kobzik, D. Pimental, T. Michel, and T. W. Smith. 1993. Abnormal contractile function due to induction of nitric oxide synthesis in rat cardiac myocytes follows exposure to activated macrophage-conditioned medium. J. Clin. Invest. 91:2314-2319.

9. Roberts, A. B., Y. Vodovotz, N. S. Roche, M. B. Sporn, and C. F. Nathan. 1992. Role of nitric oxide in antagonistic effects of transforming growth factor$\beta$ and interleukin- $1 \beta$ on the beating rate of cultured cardiac myocytes. Mol. Endocrinol. 6:1921-1930.

10. Morishita, R. G. H. Gibbons, R. E. Pratt, N. Tomita, Y. Kaneda, T. Ogihara, and V. J. Dzau. 1994. Autocrine and paracrine effects of ANP gene transfer on vascular smooth muscle and endothelial cell growth. J. Clin. Invest. 94:824-829.

11. Lane, J. R., D. A. Neumann, A. Lafond-Walker, A. Herskowitz, and N. R. Rose. 1992. Role of IL-1 and tumor necrosis factor in Coxsackie virus-induced autoimmune myocarditis. J. Immunol. 151:1682-1690.

12. Han, R. O., E. R. Phillip, K. L. Baughman, and A. M. Feldman. 1991. Detection of interleukin and interleukin-receptor mRNA in human heart by polymerase chain reaction. Biochem. Biophys. Res. Commun. 181:520-523.

13. Ulich, T. R., K. Z. Guo, B. Irwin, D. G. Remick, and G. N. Davatelis. 1990. Endotoxin-induced cytokine gene expression in vivo. II. Regulation of 
tumor necrosis factor and interleukin-1 alpha/beta expression and suppression. Am. J. Pathol. 137:1173-1185.

14. Kasten, F. J. 1973. In Tissue Culture Methods and Applications. P. F. Kruse, Jr. and M. K. Patterson, Jr., editors. Academic Press, New York. 72-86.

15. Takahashi, N., A. Calderone, N. J. Izzo, Jr., T. M. Mäki, J. D. Marsh, and W. S. Colucci. 1994. Hypertrophic stimuli induce transforming growth factor- $\beta_{1}$ expression in rat ventricular myocytes. J. Clin. Invest. 94:1470-1476.

16. Schulz, R., E. Nava, and S. Moncada. 1992. Induction and potential biological relevance of $\mathrm{Ca}^{2+}$ independent NOS in the myocardium. Br. J. Pharmacol. 105:575-580.

17. Bradford, M. M. 1976. A rapid and sensitive method for the quantitation of micrograms quantities of protein utilizing the principles of protein dye binding Anal. Biochem. 72:248-254.

18. Steiner, A. L., C. W. Parker, and D. M. Kipnis. 1972. Radioimmunoassay for cyclic nucleotides. I. Preparation of antibodies and iodinated cyclic nucleotides. J. Biol. Chem. 247:1106-1113.

19. Chomczynski, P., and N. Sacchi. 1987. Single-step method of RNA isolation by acid guanidinium thiocyanate-phenol-chloroform extraction. Annal. Biochem. 162:156-159.

20. Izzo, N. J., T. N. Tulenko, and W. S. Colucci. 1994. Phorbol esters and norepinephrine destabalize $\alpha_{1 \mathrm{~B}}$-adrenergic receptor mRNA in vascular smooth muscle cells. J. Biol. Chem. 269:1705-1710.

21. Gustafson, T. A., B. E. Markham, and E. Morkin. 1985. Analysis of thyroid hormone effects on myosin heavy chain gene expression in cardiac and soleus muscles using a novel dot-blot mRNA assay. Biochem. Biophys. Res. Commun. 130:1161-1167.

22. Meidell, R. S., A. Sen, S. A. Henderson, M. F. Slahetka, and K. R. Chien. 1986. $\alpha_{-1}$ Adrenergic stimulation of rat myocardial cells increases protein synthesis. Am. J. Physiol. 251:H1076-H1084.

23. Sadoshima, J. I., and S. Izumo. 1993. Molecular characterization of angiotensin II induced hypertrophy of cardiac myocytes and hyperplasia of cardiac fibroblasts. Critical role of the $\mathrm{AT}_{1}$ receptor subtype. Circ. Res. 73:413-423.

24. Ito, H., Y. Hirata, M. Hiroe, M. Tsujino, S. Adachi, T. Takamoto, M. Nitta, K. Taniguchi, and F. Marumo. 1991. Endothelin-1 induces hypertrophy with enhanced expression of muscle-specific genes in cultured neonatal rat cardiomyocytes. Circ. Res. 69:209-215.

25. Parker, T. G., S. E. Packer, and M. D. Schneider. 1990. Peptide growth factors can provoke fetal contractile protein gene expression in rat cardiac myocytes. J. Clin. Invest. 85:507-514.

26. Izumo, S., B. Nadal-Ginard, and V. Mahdavi. 1988. Proto-oncogene induction and reprogramming of the cardiac gene expression produced by pressure overload. Proc. Natl. Acad. Sci. USA. 85:339-343.

27. Dinarello, C. A. 1984. Interleukin-1. Rev. Infect. Dis. (Suppl. to J. Infect. Dis. ) 6:51-95.

28. Parker, T. G., K. L. Chow, R. J. Schwartz, and M. D. Schneider. 1990. Different regulation of skeletal apha-actin transcription in cardiac muscle by two fibroblast growth factors. Proc. Natl. Acad. Sci. USA. 87:7066-7070.

29. Morgan, J. P. 1991. Abnormal intracellular modulation of calcium as a major cause of cardiac contractile dysfunction. N. Engl. J. Med. 325:625-632.
30. Levitsky, D., D. De LaBastie, K. Schwartz, and A.-M. Lompre. 1991. $\mathrm{Ca}^{2+}$-ATPase and function of sarcoplasmic reticulum during cardiac hypertrophy. Am. J. Physiol. 261:23-26.

31. Mercadier, J. J., A. M. Lompre, P. Duc, K. R. Boheler, J. B. Fraysse, C. Wisnewsky, P. D. Allen, M. Komajda, and K. Schwartz. 1990. Altered sarcoplasmic reticulum $\mathrm{Ca}^{2+}$-ATPase gene expression in the human ventricle during endstage heart failure. J. Clin. Invest. 85:305-309.

32. Arai, M., N. R. Alpert, D. H. MacLennan, P. Barton, and M. Periasamy. 1993. Alterations in sarcoplasmic reticulum gene expressionin human heart failure: a possible mechanism for alterations in systolic and diastolic properties of the failing myocardium. Circ. Res. 72:463-469.

33. Feldman, A. M., E. O. Weinberg, P. E. Ray, and B. H. Lorell. 1993 Selective changes in cardiac gene expression during compensated hypertrophy and the transition to cardiac decompensation in rats with chronic aortic banding. Circ. Res. 73:184-192.

34. Movsesian, M. A., K. Mohsen, K. Green, and L. R. Jones. 1994. Calciumtransporting ATPase, phospholamban, and calsequestrin levels in nonfailing and failing human myocardium. Circulation. 90:653-657.

35. Brillantes, A.-M., P. Allen, T. Takahashi, S. Izumo, and A. R. Marks. 1992. Differences in cardiac calcium release channel (ryanodine receptor) expression in myocardium from patients with end-stage heart failure caused by ischemic versus dilated cardiomyopathy. Circ. Res. 71:18-26.

36. Takahashi, T. P. D. Allen, R. V. Lacro, A. R. Marks, A. R. Dennis, F. J. Schoen, W. Grossman, J. D. Marsh, and S. Izumo. 1992. Expression of dihydropyridine receptor $\left(\mathrm{Ca}^{2+}\right.$ channel) and calsequestrin genes in the myocardium of patients with end-stage heart failure. J. Clin. Invest. 90:927-935.

37. Yokoyama, T., L. Vaca, R. D. Rossen, W. Durante, P. Hazarika, and D. L. Mann. 1993. Cellular basis for the negative inotropic effects of tumor necrosis factor- $\alpha$ in the adult mammalian heart. J. Clin. Invest. 92:2303-2312.

38. Roberts, A. B., N. S. Roche, T. S. Winokur, J. K. Burmester, and M. B. Sporn. 1992. Role of transforming growth factor- $\beta$ in maintenance of function of cultured neonatal cardiac myocytes. J. Clin. Invest. 90:2056-2062.

39. Thaik, C. M., K. Singh, N. Takahashi, A. Calderone, and W. S. Colucci. 1994. The role of mitogen activated protein kinase and second messenger system in interleukin-1 $\beta$-induced cardiac myocyte growth. Circulation. 90:1-194.

40. Hosenpud, J. D., S. M. Campbell, and G. Pan. 1990. Indirect inhibition of myocyte RNA and protein synthesis by interleukin-1. J. Mol. Cell. Cardiol. 22:213-225.

41. Long, C. S., C. J. Henrich, and P. C. Simpson. 1991. A growth factor for cardiac myocytes is produced by cardiac nonmyocytes. Cell Regul. 2:1081-1095.

42. Mann, D. L., and J. B. Young. 1994. Basic mechanisms in congestive heart failure: recognizing the role of proinflammatory cytokines. Chest. 105:897904

43. Dec, G. W., I. F. Palacios, J. T. Fallon, H. T. Aretz, J. Mills, D. C.-S Lee, and R. A. Johnson. 1985. Active myocarditis in the spectrum of acute dilated cardiomyopathies: clinical features, histologic correlates and clinical outcome. $N$. Engl. J. Med. 312:885-890.

44. Jones, S. R., A. Herskowitz, G. M. Hutchins, and K. L. Baughman. 1991. Effects of Immunosuppressive therapy in biopsy-proved myocarditis and borderline myocarditis on left ventricular function. Am. J. Cardiol. 68:370-376. 